\title{
Wages, Talents, and Egalitarianism
}

\author{
ANDREW LISTER \\ Queen's University
}

\begin{abstract}
This paper compares Joseph Heath's critique of the just deserts rationale for markets with an earlier critique due to Frank Knight, Milton Friedman, and Friedrich Hayek. Heath shares their emphasis upon the role of luck in prices based on supply and demand. Yet he avoids their claim that the inheritance of human capital is on a moral par with the inheritance of ordinary capital, as a basis for unequal shares of the social product. Heath prefers to argue that markets do not tend to reward talent as such. The paper raises some doubts about this factual claim, and argues that sweeping the issue of talent under the rug threatens to make our theory of justice less egalitarian than it would otherwise be. The paper also addresses the objection that claims of unfairness based on the arbitrariness of the distribution of innate abilities will undermine self-respect.
\end{abstract}

Keywords: classical liberalism, desert, economic rights, high liberalism, luck, meritocracy, self-respect

JEL Classification: A13, B24, B25, J31, P14

\section{INTRODUCTION}

In a recent article in The Guardian, George Monbiot argues that neoliberalism encourages people to think that those who prosper in a competitive economic system do so on the basis of individual merit, while those who fall behind deserve their misfortune (2015). This desertbased justification of capitalism has had its defenders. In The Foundations of Morality, Henry Hazlitt argued that it was "both foolish and unjust" to insist that people who produce different amounts should be paid the same $(1964,263)$. Hazlitt drew on J. B. Clark's ethical interpretation of the marginal productivity theory of income distribution (1964, 315; citing Clark 1927, 3-4, 9). People may have a right to the fruits of their labour, but "free competition tends [...] to give to each producer the amount of wealth that he specifically brings into

AuTHOR's NoTE: The author would like to thank Huub Brouwer, Thomas Mulligan, and two anonymous referees for their comments on earlier versions of this paper. 
existence" (1964, 315). This tendency of the competitive system to give "to each what he creates" demonstrates that capitalism is not exploitative but "essentially a just system" $(1964,316)$.

Greg Mankiw has recently resuscitated the desert-based justification of market society, locating the intellectual origins of the just deserts theory in classical liberalism.

A person who contributes more to society deserves a higher income that reflects those greater contributions. Society permits him that higher income not just to incentivize him, as it does according to utilitarian theory, but because that income is rightfully his. This perspective is, I believe, what Robert Nozick, Milton Friedman, and other classically liberal writers have in mind. We might call it the Just Deserts Theory (Mankiw 2010, 295). ${ }^{1}$

In "On the Very Idea of a Just Wage", Joe Heath takes issue with Mankiw's claim that the empirical fact of reward by marginal product can be interpreted in ethical terms as reward for contribution (Heath 2018, 2; citing Mankiw 2013, 30). Wage rates in a competitive market system may not be unfair all consequences considered, but they are not (except locally and accidentally) intrinsically fair. Wages are set by supply and demand, which vary in ways that are hard to anticipate, and so incorporate a lot of luck. The function of the price system is not to reward meritorious behaviour, looking backward, but to provide incentives for adjustment to changes in tastes, technology, and social conditions that no one can accurately foresee, beyond the short term.

The founding fathers of what is today called neoliberalism recognized the importance of luck in the price mechanism. Frank Knight (1923), Friedrich Hayek (1960, 85-102), and Milton Friedman (1962, 16176) all recognized the inevitable role luck plays in supply and demand, and so denied that reward according to marginal product was intrinsically fair, apart from the beneficial social consequences of this pattern of distribution. ${ }^{2}$ They had a second reason for rejecting the desert-based justification of capitalism, however, which was that it is a matter of luck whether one is born with a lot of talent or little. Inheritance of productive capacity is not in itself a valid basis for

\footnotetext{
${ }^{1}$ See also Mankiw (2013, 32-33).

${ }^{2}$ For his part, Nozick rejected all patterned conceptions of distributive justice, including merit and desert, in favour of a natural rights approach that assessed the justice of holdings based on whether they originated in just acquisition and transfer, indefinitely iterated, with deviations appropriately rectified (Nozick 1973, 150-153).
} 
superior economic reward, they pointed out, no more than is inheritance of ordinary property.

Heath avoids this second line of criticism, preferring to argue that labour markets do not in fact reward superior natural ability, to any great extent.

[W]hen someone like Mankiw argues that the rich are merely being paid in accordance with their talents, it is overkill to respond, as Solow and others did, 'yes, but they have done nothing to deserve those talents!' [...] A much less controversial approach is simply to deny that wages are a reward for talent. For every story of how talent has been richly rewarded by the market, one can find a story of how markets have failed to reward some talent, or of how an untalented person has earned some rich reward. Thus the entire question of natural ability or talent is simply orthogonal to the debate over whether the particular wage rates determined by competitive markets are justifiable (Heath 2018, 21, emphasis in original).

In short, it doesn't matter what philosophical position we take on whether talent is a basis of economic desert, because markets don't reward talent, to any significant extent. I would like to argue, to the contrary, that if we sweep the issue of talent under the rug, we are likely to end up with a theory of justice that is less egalitarian than it would otherwise be.

To make this case, the paper explores the connection between classical liberalism, of the kind championed by Knight, Hayek, and Friedman, and the egalitarian liberalism of Rawls. Knight, Hayek, and Friedman all recognized the moral arbitrariness of the distribution of natural talent, and so rejected the just deserts justification of the competitive economic system. That didn't make them egalitarians. They used the equivalence of natural and social inheritance to accuse egalitarians of inconsistency. How can you object to inheritance of wealth if you don't also object to inheritance of talent? Rawls agreed that both grounds for economic inequality are morally arbitrary, but claimed that neither is justified unless it benefits the worst off. His difference principle can thus be seen as arising out of accepting the equivalence of natural and social inheritance, but then claiming that such arbitrary inequalities must benefit everyone in order to be acceptable, instead of simply raising the average share. Denying that inequalities of talent are significant or that they correlate with wage 
differences might lead us to conclude that inequalities don't need to raise the worst off, so long as they arise in a context of fair equality of opportunity.

Section 2 sets out the free-market critique of desert-based justifications of capitalism, focusing on the claim that natural and social inheritance are on a moral par, as far as the distribution of income is concerned. Section 3 explains the role this 'equivalence thesis' plays in the justification of the difference principle, and the risk Heath's avoidance strategy poses to egalitarianism. Section 4 defends the equivalence thesis against those who think that natural and social inheritance are not on a moral par. Section 5 addresses the worry that grounding egalitarianism on the arbitrariness of the distribution of natural ability will undermine self-respect.

\section{Classical Liberals Against the Just Deserts Justification of CAPITALISM}

Heath suggests that the philosophical discussion of wages and talent has its origins in Rawls's comment that the distribution of income and wealth is determined by the distribution of natural assets, differentially developed by unequal familial and social conditions (Heath 2018, 17; citing Rawls 1999, 62-63). In fact, Rawls was drawing a long tradition of free-market criticism of the desert-based justification of capitalism. ${ }^{3}$

In his 1923 essay "The Ethics of Competition", Knight accepted that in a competitive economic system, income tends to be distributed according to marginal product, but denied that this pattern of reward constituted "a sound ethical social ideal" (Knight 1923, 588) or "an ethical measure of desert" (596). The capacity to produce things that happen to be in high demand does not establish "an ethical claim to a superior share of the social dividend", Knight argued, "except to the extent that the capacity is itself the product of conscientious effort" (599). Inequalities of reward due to variations of supply and demand are not intrinsically fair, even if permitting such inequalities has social benefits.

Heath notes that, in The Mirage of Social Justice, Hayek exempted market outcomes from moral assessment (Heath 2018, 3; citing Hayek 1976). However, in The Constitution of Liberty, Hayek argued that markets did poorly, when assessed by the standard of individual desert.

\footnotetext{
${ }^{3}$ This section of the paper draws on Lister $(2017,50-54)$.
} 
Market prices are not justified by the merit individuals show in trying to make a contribution, assessed by standards that would warrant praise or blame, but by the usefulness of what they end up producing, for the satisfaction of other people's wants (Hayek 1960, 85-102). No one can predict with any precision how tastes and technology will evolve; two people could work with equal diligence and prudence but end up producing things of greatly differing value to others. Given the limited information individuals have at their disposal, prices based on supply and demand will incorporate a lot of luck, and must do so if they are to send the right signals, that is, the signals that will shift resources to where they can be best used. Prices are justified by the consequences of the information they communicate, not by their fit with the praiseworthiness of people's past efforts. ${ }^{4}$

Although he abandoned many of Knight's qualms about capitalism (Burgin 2012, 188), Friedman agreed that a competitive economic system could not be justified on the basis that it rewarded the deserving. He began his chapter on income distribution in Capitalism and Freedom with what could easily be mistaken for an endorsement of the just deserts view: "The ethical principle that would directly justify the distribution of income in a free market society is "to each according to what he and the instruments he owns produces'” (1962, 161-162). The conditional and the implicit distinction between direct and indirect justification are significant. Friedman concluded that distribution according to productive contribution "cannot in and of itself be regarded as an ethical principle [...] [but] must be regarded as instrumental" (165). The function of payment in accordance with product is to allocate resources efficiently without compulsion (167).

The role of luck in determining wages is made particularly clear if we heed Heath's insistence that a market economy involves reciprocal causation. Differences in individual productivity may seem to be the driving force behind differences in wages, but this unidirectional way of thinking ignores the fact that differences in the scarcity of workers in different locations affect what they're hired to do. Firms hire additional workers up until the point at which the revenue the last worker generates is equal to the cost of hiring that worker (and then pay all workers of that type the same wage). Other things equal, hiring

\footnotetext{
${ }^{4}$ Nozick argued that Hayek's rejection of desert didn't go far enough. Distribution according to benefits to others is only one strand of the complex, evolving pattern of market rewards, and not a criterion of justice (Nozick 1974, 158-159).
} 
additional workers of the same type brings declining marginal benefits, because, for example, additional workers are hired to fulfill lower value tasks. Therefore, if that type of worker is scarcer in one place than another, workers in the higher-scarcity location will end up being more productive on average, even if they are identically skilled and hardworking, in part because they will not be hired to fulfill low-value tasks. It is no more true that workers' marginal product determines their wage rate than it is that their wage rate determines their marginal product; as Heath explains, these properties are jointly determining (Heath 2018, 14).

It is true that in the absence of distortions such as borders, workers will move from the region in which their skills are abundant to regions in which they are scarce, and that firms will relocate from regions in which the skills they require are scarce, to regions in which they are abundant. In equilibrium, therefore, levels of reward will equalize for workers with the same skills. Given that the world is always changing, however, and that individuals inevitably have limited information, the costs of adjustment to disequilibrium are not guaranteed to be fair. Consider the impact of technological change, and how tastes evolve in response to new possibilities of consumption. People can't be blamed for not anticipating at age 16, when they are making decisions about school and career, what the demand for different skills will be when they are 36 or 56.

In The Road to Serfdom, Hayek argued that the human capacity for invention and innovation presents a fundamental limit on the possibility of comprehensive social planning, even on the part of scientific experts (Hayek 2007, 69-73). The same limits apply even more strongly to ordinary people. The magic of the market is to aggregate dispersed information, allocating resources efficiently (Hayek 1945). The result may not be unfair all things considered, but it is not fair in itself, considered apart from the social consequences of this mechanism of distribution. Heath is right that we are very far from the ordinary ("concrete") idea that individual contribution determines one's level of reward (Heath 2018, 15). A change of mindset is required in shifting from everyday interactional thinking to a systems-level view. The pricedifferential for labour of the same type (when the market is in disequilibrium) cannot be justified as a reward for greater contribution, looking backward; it can only be justified as a signal, looking forward, as a means of generating prosperity. 
The importance of luck in the fluctuations of supply and demand was not the only reason Knight, Hayek, and Friedman had for rejecting the ethical interpretation of the marginal productivity thesis, however. They also noted that wages are influenced by the inheritance of talent, and that the inheritance of scarce human capital is no more a basis of desert than is the inheritance of scarce financial capital. Knight pointed out that in a competitive economic system, income goes to owners of factors of production, and that "ownership of personal or material productive capacity is based upon a complex mixture of inheritance, luck, and effort, probably in that order of relative importance" (Knight 1923, 598). Of these, only effort could have ethical significance, in Knight's view, since inheritance was itself a form of luck. If anything, superior innate ability "represents an obligation to the world rather than a claim upon it" (599). Knight concluded that there was no ethical significance to the distinction between income from labour and income from other sources. As he put it in a later essay on socialism that Hayek would cite, "[t]here is no visible reason why anyone is more or less entitled to the earnings of inherited personal capacities than to those of inherited property in any other form" (Knight 1940, 277; cf. Knight $1947,151)$. In short, Knight argued for the moral equivalence of natural and social inheritance as the basis for claims to a share of what he called "the social dividend" (Knight 1923, 588, also 599).

We find the same recognition of the moral arbitrariness of the distribution of talent (innate ability) in Hayek, along with the same accusation of inconsistency directed against egalitarians.

[T] he value that the performance or capacity of a person has to his fellows has no necessary connection with its ascertainable merit in this sense [i.e. the attributes of conduct that make it deserving of praise]. The inborn as well as the acquired gifts of a person clearly have value to his fellows which does not depend on any credit due to him for possessing them. There is little a man can do to alter the fact that his special talents are very common or exceedingly rare. A good mind or a fine voice, a beautiful face or a skilful hand, and a ready wit or an attractive personality are in large measure as independent of a person's efforts as the opportunities or experiences he has had. In all these instances the value which a person's capacities or services have for us and for which he is recompensed has little relation to anything we can call moral merit or deserts (Hayek 1960, 94). 
It is socially beneficial to let wages track scarcity of ability, but not intrinsically fair, given that people's talents are to a significant extent inherited.

In the passage above, Hayek uses 'merit' and 'deserts' as if these terms are interchangeable. He adds 'moral' to 'merit' to underscore the fact that he is talking about conduct worthy of praise, rather than what a person ought to get all things considered (which for efficiency's sake must ordinarily be whatever the market will bear). Hayek's usage is consistent with contemporary philosophical parlance, according to which desert refers to attitudes or modes of treatment towards a person called for by facts about that individual's attitudes or conduct (Miller 1999, 133; Scanlon 2013, 101). To be sure, we do say that those in need deserve to be helped, even though need is not a kind of conduct. For this reason, some writers speak of merit when individual performances are in question, reserving 'desert' for what an individual ought to get all things considered. On that usage, however, incentives based on social benefits give rise to individual desert (Mulligan 2018, 67-68). I prefer to restrict 'desert' to one component of what people ought to get all things considered, because I think of desert as primarily a non-instrumental and expressive relation of fit between a person's conduct and the responses of others (Feinberg 1970; cited by Miller 1999, 136 and Scanlon 2013, 101).

Like Knight, Hayek used the inheritance of talent to accuse egalitarians of inconsistency. He quoted Plamenatz's summary of Tawney's position on equality of opportunity: "all inequalities that rest on birth and inherited property ought to be abolished and none remain unless it is an effect of superior talent and industry" (Hayek 1960, 89; cf. Plamenatz 1956, 100). Hayek's response was that "no more credit belongs to him for having been born with desirable qualities than for having grown up under favorable circumstances" (Hayek 1960, 89). Neither good genetic luck nor good social luck has anything to do with moral merit, Hayek insisted, citing Knight's equivalence thesis (440). Some are born to wealthy parents, others to kind and intelligent parents; neither implies any superior merit on the child's part, nor can one be more unjust than the other.

Friedman frankly acknowledged that much economic inequality results from "initial differences in endowment, both of human capacities and of property" (1962, 163-164): 
Most differences in status or position can be regarded as the product of chance at a far enough remove. The man who is hard working and thrifty is to be regarded as 'deserving'; yet these qualities owe much to the genes he was fortunate (or unfortunate?) enough to inherit (165-166).

It is striking, given Rawls's later controversial comments on the influence of family circumstance on willingness to make an effort, ${ }^{5}$ that in this passage Friedman is discussing inheritance of character, not simply inheritance of intelligence or strength or good health. ${ }^{6}$

Like Knight and Hayek, Friedman directed most of his critical fire against the view that there is an important moral difference between inequalities in inherited talents and inequalities in inherited wealth. He inquires, "[i]s there any greater ethical justification for the high return to the individual who inherits from his parents a peculiar voice for which there is high demand than for the high returns to the individual who inherits property?" (Friedman 1962, 164). In other words, if you object to inheritance of wealth, why don't you object to inheritance of talent too?

At this point it is worth pausing to explain what we mean by 'talent', and to ask whether it makes sense to speak of inequalities of talent being innate. Let us say that 'ability' refers to the capacity to do something well, assuming agreement on standards of appraisal. 'Talent' can then refer to the potential to develop ability, given good environmental conditions. In principle we could average over different activities to create aggregate measures of potential ability. But which activities are relevant? It's clear from the quotes above that Knight, Hayek, and Friedman were concerned with differences in talent at producing things that others want to purchase. Differences in potential abilities may be innate, but they only amount to inequalities given that

\footnotetext{
5 "That we deserve the superior character that enables us to make the effort to cultivate our abilities is also problematic; for such character depends in good part upon fortunate family and social circumstances in early life for which we can claim no credit. The notion of desert does not apply here" (Rawls 1999, 89, see also 64). People have taken this comment to mean that nothing can be deserved. According to Michael Sandel, Rawls accepted only the neighbouring but distinct notion of legitimate expectations, that is to say the entitlements that arise in virtue of people behaving in ways recognized by social institutions (Sandel 1982, 71-2).

${ }^{6}$ For further evidence of Friedman's attitudes towards desert, see the following clip: https://www.youtube.com/watch?v=hsIpQ7YguGE, at 2:35. When asked whether women who are currently paid less than men for the same work deserve to be paid less, Friedman answers “I don't think desert has anything to do with it. First of all, I think desert is an impossible thing to decide. Who deserves what? Nobody deserves anything. Thank God we don't get what we deserve!"
} 
people prefer to purchase some things rather than others. As Milton Friedman pointed out, Frank Sinatra's voice might not have been so highly valued had he been born in India rather than the United States (Friedman and Friedman 1979, 22). Heath cites the case of symphony musicians who are very talented, but not highly paid $(2018,20)$. These examples show that while innate talents differ, they only command unequal reward as a result of the way they fit with aggregate consumer preferences.

Moreover, the design of social institutions can make it easier or harder for individuals with particular talents to be productive. For example, someone with a physical disability who could be productive at software design may not be able to contribute if schools and workplaces are not accessible. Thus a person's level of productive capacity depends to some extent on both cultural and institutional context. It is therefore misleading to describe inequalities of talent as natural or innate, even though differences in talents have a genetic basis. Differences of innate potential only become inequalities in a social context.

However, the cultural and institutional relativity of productive potential is only partial. There are presumably some general abilities that are useful to others across a wide range of social and cultural contexts, such as intelligence, strength, and a cheerful disposition. Whatever the true extent of cultural variability, it would be wishful thinking for us to assume that all people are born with equal potential to produce things others want, or that we could produce this state of affairs by reforming our preferences. The case of highly-talented but low-paid symphony musicians simply shows that talent is not the only factor influencing wages, not that it is nothing. Talent at an activity for which there is no demand yields no reward, but within a given occupation or activity, we would expect that superior ability would be associated with higher reward. It would be nice to think that for any two people, one person's greater potential in one dimension will always be offset by the other person's greater potential in another, but that need not be the case. (For all I know, Heath is cleverer than me and a better hockey player.) Finally, even if it is true today that innate differences of productive potential are small, they are not guaranteed to be so in the future, as control over the genes of our offspring becomes available to some but not to others.

In support of his scepticism that markets reward talent, Heath cites evidence that innate ability does not explain inter-industry wage 
differentials (Heath 2018, 3). This result doesn't show that markets ignore talent, but simply that unobserved talent differentials are not the explanation for the "anomaly" (Thaler 1989, 181) that people in the same occupation in different industries often earn different wages. If prices are based on supply and demand there should be one price for workers with the same skill set. Yet secretaries, janitors, and managers in some industries consistently tend to be paid more than secretaries, janitors, and managers in other industries, despite the fact that within each category workers are performing the same functions (Thaler 1989, 182-183). One explanation would be that some industries systematically hire better workers than others, within the same occupations, but Thaler found little evidence in favour of this "unobserved quality" hypothesis (184). It is consistent with this result that people with more talent earn more within the same occupation and industry, or tend to go into more highly rewarded occupations. Thaler's conclusion was that "firms pay attention to equity in setting wages" (191). That's not evidence that marginal productivity diverges from talent, but that wage patterns diverge from the standard model of competitive markets.

To the extent that there is a problem of inequality of talent, Heath suggests that it can be dealt with by encouraging competition, in order to eliminate the market power that superstars such as Lionel Messi enjoy (Heath 2018, 3, also 18). Yet even if we imagine that highly skilled people are sufficiently numerous so that they are price-takers, and cannot command above-market returns by restricting the supply of their services, the scarcity of their abilities (and innate talents) will earn them a premium over others who work as much and equally conscientiously. Eliminating market power eliminates people's capacity to affect prices by restricting supply, but it doesn't eliminate inequalities of reward beyond what would be justified by differences of effort and difficulty.

I draw a number of conclusions from this discussion. First, it is clearly wrong for Mankiw to attribute a just deserts theory to classical liberals such as Friedman. Second, although productive ability depends on social context, it is doubtful that people are born with equal potential productive ability, or could have equal productive ability, if only we designed our institutions differently. Third, we should not be persuaded by Heath's claims that talent is orthogonal with respect to wages and that eliminating market power would make wage differences fair. 


\section{The Equivalence Thesis AND The Difference PrinCIPLE}

Knight, Hayek and Friedman were wrong to suggest that egalitarians in general were inconsistent in their attitudes toward social and natural inheritance. Many on the left did object to the fact that in a market system the product of collective labour tends to be distributed unequally according to innate ability. There was an active debate among socialists and left-liberals in the early twentieth century about the necessity and the legitimacy of incentives, and the so-called "rent of ability" (Jackson 2007, 72). On the one hand, it seemed unfair that superior ability should by itself command a greater share of the social product, holding constant variables such as conscientious effort and difficulty of the task. On the other hand, without a major transformation of human character, pay differentials would be necessary in order to induce those with scarce abilities to apply them where most needed, and with sufficient industry. Left-liberals and socialists agreed that such incentives were not strictly fair, but a compromise; where they tended to disagree was about the extent to which ethical motivations might one day replace self-interested ones (Jackson 2007, 74-76).

Rawls's focus on the structure of basic social institutions may have deflected attention away from personal ethics towards public policy, and in so doing obscured the question of whether incentives are fully just, or merely justified in the circumstances, given people's lack of concern for justice. Yet his answer to Knight's equivalence thesis built upon the socialist/left-liberal tradition. Rawls explicitly agreed with Hayek that there was an inconsistency in objecting to social but not natural inheritance: "[U]nequal inheritance of wealth is no more inherently unjust than unequal inheritance of intelligence; as far as possible the inequalities founded on either should satisfy the difference principle" (Rawls 1967, 71; citing Hayek 1960, 90). Even with achievement-based selection to positions and with conditions of development in childhood equalized (the position Rawls called "Liberal Equality" [1999, 57]) the distribution of income and wealth would be influenced by the distribution of natural assets (Rawls 1999, 64). It was Rawls's acceptance of the equivalence thesis that led to "Democratic Equality" (Rawls 1999, 64-5), his preferred interpretation of his second principle, which combined fair equality of opportunity with the demand that inequalities between positions should raise lower positions (the Difference Principle). 
The equivalence thesis is that inherited talent has the same moral status as inherited financial or physical capital when it comes to the distribution of the social product. So stated, the thesis is consistent with two different claims: that differences of innate productive ability do not provide a positive reason for inequalities of income (other things being equal), and that there is a reason against letting distributions be sensitive to these differences (other things being equal). ${ }^{7}$ One way we might distinguish Rawls from the classical liberals is to say that Rawls sees something wrong with situations in which reward tracks innate talent (other things being equal), whereas Knight, Hayek, and Friedman simply don't see any reason in its favour (until we consider the consequences of this pattern of distribution). I don't think it's possible to know for sure whether they thought such inequalities unfair or simply not-fair, because they were not working at this fine-grained level of ethical analysis. What is clear is that in Rawls's view, inequalities of reward that track innate talent do require justification, and that maximizing aggregate or average income is not a sufficient justification. Inequalities of innate ability are not a basis of desert of superior economic reward. If for efficiency's sake we're going to let wages be determined by supply and demand, we will unintentionally, but predictably, allot those persons with scarce innate abilities greater reward. Such inequalities are not justified simply because they make us wealthier in the aggregate; they need to benefit the worst off.

To see the importance of the assumption that people are born with different levels of innate productive potential, suppose that there is little variation in innate capacities, or that wages do not vary with innate ability, as Heath suggests. These factual claims do not force us to conclude that the difference principle is wrong where such inequalities do exist, but they raise a question about whether the principle is needed where they don't. If wages don't vary (much) with innate ability, fair equality of opportunity would be sufficient for distributive justice (assuming protection of basic liberties).

It's important to insist that fair equality of opportunity is not in general sufficient for justice, however. Even if we had fully equal conditions of development during childhood and fully merit-based selection to positions, higher positions would tend to be filled not just by those who happen to have a taste for responsibility and achievement,

\footnotetext{
7 The distinction between there being no reason in favour of such sensitivity or a reason against it is from Cohen $(2008,166)$.
} 
but by those with greater talents. If someone proposes to organize society strictly on the basis of private property, private childrearing, and free markets, we need to be able to object that the fruits of our collective labour will be divided up according to good or bad fortune in the parental lottery, in both its natural and social dimensions. Without the assumption that levels of innate ability vary, there would be no apparent reason to object to what Rawls called 'Liberal Equality'. It would be sufficient for justice (assuming satisfaction of prior principles) to have roughly equal conditions of development through adolescence and achievement-based selection to positions thereafter. Heath's avoidance strategy for dealing with questions of unequal natural ability therefore threatens to make our theory of justice less egalitarian than it would otherwise be.

I say only that this strategy 'threatens' rather than 'implies' less egalitarianism. The factual claim that levels of innate ability don't correlate with wages can't force us to repudiate the normative principle that if there were such a correlation, it wouldn't be justified unless it benefited the worst off. It is important, however, not to mistake locally valid from generally valid principles. Where there is no significant variation in the innate bases of productive capacity, or where wages don't correlate with talent, Liberal Equality yields the right conclusions about policy. If there are major differences in productive capacity, however, and if left to itself the market would reflect these differences, then even with fair equality of opportunity, inequalities of reward between positions would involve morally arbitrary inequality that does not benefit all. Those born with scarce talents would be able to attain positions yielding superior rewards even if their being able to do so did not benefit the worst off. It's important that we do not lose sight of the fact that fair equality of opportunity is sufficient for distributive justice (assuming satisfaction of prior principles) only where there is no significant variation in the innate bases of productive ability. Denying the existence of such differences in ability risks camouflaging the fact that inequalities between positions need to satisfy this condition, and would still need to do so even if conditions of development in childhood and adolescence were more equal.

One might question whether the Difference Principle is really egalitarian, either in the strict sense of attributing intrinsic value to equality, or in the looser sense of favouring policies that would promote 
greater equality than exists at present. Considered by itself, ${ }^{8}$ the principle could justify arbitrarily large inequalities, if the facts are such that it takes big gains for the better off to generate small gains for the worse off. Yet it's not sufficient for a given regime to pass muster, that it leaves the worst off better off than they would be under perfect equality, or for a change in regime to leave the worst off better off than they were under the status quo. To satisfy the difference principle, one needs to show that each increment of inequality benefits the worst off, such that there is no more equal alternative that would benefit the worst off more. Just how egalitarian the principle is depends on the details of its formulation. Are inequalities merely permissible or mandatory if they raise or don't lower the lowest position? (Cohen 2008, 29, note 6). Another important issue is whether we interpret the principle as requiring that we maximize long-run growth in the position of the worst-off (Brennan 2007; Tomasi 2012, 235), or that we maximize the position of the worst off today, subject to a just savings principle (Lister 2018). Of course, whether proper application of the principle would result in greater equality depends heavily on political and economic facts as well. Without hoping to resolve such issues, I simply wish to make the point that holding other aspects of one's theory constant, adding the requirement that inequalities must benefit the worst off (in whatever form) tends to make the theory more egalitarian, unless the requirement is replacing an even stricter constraint on inequalities.

\section{QUESTIONING THE EQUIVALENCE THESIS}

Despite the fact that it receives support from classical liberals as well as egalitarians, many people find the equivalence thesis unacceptable. David Miller notes that meritocracy enjoys widespread support (Miller 1996, 278; citing evidence discussed in Miller 1991). By "meritocracy", Miller refers to "the ideal of a society in which each person's chance to acquire positions of advantage and the rewards that go with them depends entirely on his or her talent and effort" (Miller 1996, 277). I can still deserve to win the race even if I was born with long legs and you with short, at least so long as it wasn't impossible for you to win (Sher 1979, 371). Support for meritocracy normally goes along with some

\footnotetext{
${ }^{8}$ The difference principle is limited by prior principles. People's opportunities to have a political say cannot be too unequal, and their conditions of development in childhood cannot be too unequal, so that people born in different social locations have roughly equal opportunities to develop their talents and attain higher positions (Rawls 1999, 70; Estlund 1998, 110; Williamson and O’Neill 2009, 5)
} 
commitment to ensuring that everyone has a real chance to develop and exercise their talents. People need a fair opportunity to deserve (Olsaretti 2004, 31). Indeed, it can be argued that ensuring adequate or not-too-unequal conditions of development in childhood and adolescence is an essential part of meritocracy, and that if there is too much inequality in developmental conditions, some affirmative action is called for on grounds of merit, as a way of compensating for the fact that past disadvantage makes present achievement underestimate future potential (Miller 1992, 179).

When the prize is esteem based on admiration for exercise of abilities, and the context is a local, voluntary practice such as an athletic competition, desert claims are not objectionable, despite the fact of unequal innate abilities. Participation in the economic system is not voluntary, however, and the prize consists of economic goods whose production requires the labour and cooperation of others. Consider a job that leads to personal and intellectual development, that is highly paid, and that involves superior social status, such as being a university professor or a doctor. Even if conditions of development in childhood were identical, people would not have equal opportunity to occupy these positions, because access is awarded based on achievement that demands scarce capacities, such as intelligence. Rawlsian fair equality of opportunity demands that people with the same innate abilities have the same chances of attaining such positions; the probability of becoming a professor or doctor should not differ systematically across social classes. Those who have not been blessed with superior cleverness might want a chance to play these roles, however. Why are they denied an equal chance, if they are willing to work just as hard and as conscientiously as other candidates? Their interests matter just as much as do the interests of those blessed with greater abilities.

The answer must be that assignment based on achievement yields greater social benefits than would assignment based a simple lottery, or a lottery across all willing to put in equal effort. Given the rule of meritbased selection to positions (a rule justified by its social benefits), the most skilled person should get the job of brain surgeon. But the rule of merit-based selection to positions cannot be justified by appeal to desert. Greater scarcity of ability to produce what others want does not by itself generate a moral claim to a greater share of the social product, independent of social benefits. 
We do want to provide opportunities for people to develop and exercise their talents, in the economic sphere as in art and sport. Those who seek to do so in ways that are personally costly but that provide benefits to others ought to be rewarded for their efforts. However, getting a greater share of the social product (beyond what is justified by greater costs of one's efforts) is not necessary in order to have the opportunity to develop one's talents. A lower salary for university professors would not have denied me the opportunity to be a professor. The justification for higher reward must be based on incentives, and benefits to the worst off.

Thomas Mulligan has recently argued that there is a crucial difference between natural and social inheritance, which is that one's genes constitute (in part) one's identity, whereas one's environment during childhood shapes one's opportunities to develop one's talents (2018, 167-168). Natural assets are "metaphysically necessary" in the sense that they "constitute the person" (173). It was not a matter of luck that I was born clever, because had I not been born that way I would not have been the same person; there is no stable 'me' on both sides of the counterfactual. In contrast, it is possible to imagine that I might have grown up in worse social conditions, and so had less opportunity to develop my abilities, and thus never become a university professor, but still otherwise have been me.

The objection to this use of identity against the equivalence thesis would be that it is as morally problematic for us to distribute economic goods on the basis of metaphysically necessary properties, such as innate ability or sex (without further justification), as it is to distribute economic goods on the basis of properties that are not metaphysically necessary, such as parental social status. Mulligan acknowledges this response (177), but says that it too relies on an untenable distinction between a person's identity and their genetic endowment (177). The reason a particular person is worse off than another can't be because that person had endowments $\mathrm{X}$ rather than endowments $\mathrm{Y}$, because if they'd had different endowments they would be a different person; a version of the non-identity problem seems to block individualized complaints of inequality on the basis of essential characteristics. But we can say that one person is worse off than another because we have chosen to allocate goods on the basis of a morally arbitrary characteristic. It is morally bad, other things equal, to use sex as a criterion for allocating income, even if sex is constitutive of identity. I 
may not be able to say 'I would have less income were I a woman' (because it wouldn't be the same 'I'), but I can say 'it's not right that we should give less to women than men simply because they are women'.

The arbitrariness of the distribution of innate talents undermines claims that market rewards are deserved, but it does not imply any general rejection of desert. In the most basic sense, desert refers to a non-instrumental relation of fittingness between a characteristic or activity that is substantially under an individual's control (the "basis" of desert), and a response that is called for on the part of others (Feinberg 1970, 58). So, for example, if you sing a beautiful song, you deserve my praise and admiration, while if you give me a lift to work when my car battery has died, you deserve my gratitude. The basic things people deserve are "responsive attitudes" (Feinberg 1970, 70), with modes of treatment being deserved only derivatively as expressions of these attitudes. It is this expressive and relational aspect of desert that makes at least the core cases of desert non-instrumental (Feinberg 1970, 82). Egalitarians have no reason to reject desert in this sense; they need only deny that scarcity of ability is by itself a basis of desert of superior economic reward.

The core idea Rawls shared with Knight, Hayek, and Friedman is that the possession of scarce innate ability does not by itself ground any claim to a greater share of the products of our collective labour. As Thomas Scanlon puts it, "mere scarcity is not a desert basis at all" (2013, 114). However, it could be that willingness to make a contribution is. We can deny that reward should be in strict proportion to contribution without claiming that willingness to contribute is entirely irrelevant. Hence, for example, we might entertain a doubt about the proposal to institute a basic income that is "obligation free" (Van Parijs and Vanderborght 2017, 21).

\section{TALENT, SELF-RESPECT, AND EgALITARIANISM}

Unequal talent does not imply unequal moral worth, but in practice it is difficult to affirm the one without being seen to affirm the other. Part of what motivated the pro-market critique of the desert-justification for capitalism was a worry about the stability of the competitive economic system, when defended as a way of giving the deserving what they are due. Hayek cited Michael Young and Anthony Crosland's fear that inequality would be more painful for the worse off if they thought they deserved their misfortune, and if the rich thought they deserved theirs 
(Hayek 1960, 98, 441-442; citing Young 1958 and Crosland 1956, 235). ${ }^{9}$ In the same vein, Friedman pointed out that "we are generally much readier to accept inequalities arising from chance than those clearly attributable to merit" (Friedman 1962, 166). Superior luck in the genetic lottery is no merit. We do take pride in our abilities, however, whether inherited or not. Emphasizing the role of talent in determining levels of reward is therefore a double-edged sword, as far as self-respect is concerned. It may be true that inherited abilities are no more deserved than inherited wealth. Yet recognizing the influence of the genetic lottery on levels of economic reward risks exacerbating the problem of self-respect if it is invoked as the basis for equalizing redistribution.

Rawls thought that the difference principle expressed respect for others as ends, thereby supporting everyone's self-respect (Rawls 1999, 154-157). He famously described the distribution of natural assets as a common asset, adding that "by abstaining from the exploitation of the contingencies of nature and social circumstance [...] persons express their respect for one another in the very constitution of their society" (156). Some statements of this abstention can seem disrespectful, however. "When racial and sexual injustice have been reduced", Thomas Nagel once said, "we shall still be left with the great injustice of the smart and the dumb, who are so differently rewarded for comparable effort" $(1973,362)$. Nagel is right that superior innate intelligence does not by itself generate a claim to superior reward, but his way of stating the point causes discomfort. Does his statement not risk justifying privileges for 'the smart' while stigmatizing 'the dumb' as intrinsically lesser than others?

Jonathan Wolff argues that insisting on exact distributive fairness will come at an unacceptable cost in terms of mutual respect, if it requires that individuals reveal facts about themselves that are perceived as shameful $(1998,113-115)$. When times are good and jobs plentiful, gaining unemployment benefits might require demonstration that one is lacking in talent, to prove that one is not shirking, which would be demeaning. Wolff concludes that income support ought to be unconditional, even at the price of some distributive unfairness (Wolff 1998, 121).

Even if income support is unconditional, however, the public rationale for redistributive policies might pose a problem in terms of

\footnotetext{
${ }^{9}$ Rawls argued that his principles would not lead to society that was meritocratic in Young's sense (Rawls 1999, 91; citing Young 1958).
} 
self-respect. Elizabeth Anderson argues that in the case of luck egalitarianism "general knowledge of the grounds upon which citizens laid claim to special aid would be stigmatizing" (Anderson 1999, 306). She imagines an insulting letter that might written by a "State Equality Board" to "the stupid and the untalented: [...] Because of the misfortune that you were born so poorly endowed [...], we productive ones will [...] let you share in the bounty of what we have produced with our vastly superior [...] abilities" (305). Even if the letter is never written, common knowledge that this is how compensation is justified undermines selfrespect, she claims. It is tempting to say that everyone is equally talented just differently so, or to deny that market rewards track innate ability. Strikingly, Anderson contrasts luck egalitarianism's commitment to a principle with her own position's commitment to a factual claim:

It is instructive to consider what democratic equality says to those with low talents. Equality of fortune would offer compensation to those with low talents, precisely because their innate inferiority makes their labor so relatively worthless to others, as judged by the market. Democratic equality calls into question the very idea that inferior native endowments have much to do with observed income inequalities in capitalist economies (325).

The factual claim that native ability does not correlate with income does not compete with the principle that it ought not (other things equal). Anderson seeks to avoid the question of whether, or under what conditions, inequalities of innate ability justify unequal economic reward. Yet her own view requires an answer to this question. Some people need more resources than others in order to achieve the requisite level of capacity to function as a citizen. Such inequalities do not arise only because of biases in the built environment, but also because people are born with different abilities. On both views, recognition of differences of innate ability play a role, whether what is relevant from the point of view of justice is these differences give rise to lesser capacity to function as a citizen, or lesser capacity to flourish generally. The potential for stigma based on lesser ability arises in both cases.

I don't think it is a coincidence that Anderson's conception of democratic equality ends up being less egalitarian than Rawls's. Whereas the difference principle requires that inequalities between positions raise lower positions, Anderson's conception of democratic equality involves what she calls a "less demanding form of reciprocity": if all 
citizens enjoy a set of real freedoms sufficient to function as a social equal, "income inequalities beyond that point do not seem so troubling in themselves" (326). Not as troubling, it is true, but still troubling, if they are correlated with possession of scarce innate ability, and if permitting these economic inequalities does not benefit the worst off.

There is a real tension here, between the requirements of distributive fairness and the expressive effects of incautious statements of fairness's rationale. What can we do to lessen it? We can avoid stating the point about the moral arbitrariness of the distribution of talent in overly stark terms, as if there exists a comprehensive pre-social ranking of talent. We can insist that greater inherited ability does not imply greater worth or importance. We can point out that market rewards reflect what people (with money) want to purchase, thus neglecting public goods that individuals will not generally have an incentive to purchase on an individual basis. And we can remind people that a competitive economic system will tend to reward competitiveness rather than a scrupulous concern for truth, kindness, and reciprocity (Knight 1923, 611).

\section{CONCLUSION}

In this paper I have described how prominent classical liberals rejected the desert-justification of capitalism, in part because of the moral equivalence of natural and social inheritance as bases for the division of the social product. Egalitarians insist that morally arbitrary inequalities must benefit the worst off, not just maximize aggregate prosperity. Without the premise that there is a distribution of inherited talent, inequalities would be acceptable so long as they were consistent with fair equality of opportunity. Heath's and Anderson's avoidance strategy threatens to make our theory of distributive justice less egalitarian, by obscuring the case for the difference principle.

\section{REFERENCES}

Anderson, Elizabeth. 1999. "What Is the Point of Equality?" Ethics 109 (2): 287-337.

Brennan, Jason. 2007. "Rawls' Paradox." Constitutional Political Economy 18 (4): 287299.

Burgin, Angus. 2012. The Great Persuasion: Reinventing Free Markets Since the Depression. Cambridge, MA: Harvard University Press.

Clark, John B. 1927. The Distribution of Wealth: A Theory of Wages, Interest, and Profits. New York, NY: MacMillan.

Cohen, Gerald A. 1989. “On the Currency of Egalitarian Justice.” Ethics 99 (4): 906-944. 
Cohen, Gerald A. 2008. Rescuing Justice and Equality. Cambridge, MA: Harvard University Press.

Crosland, Anthony. 1956. The Future of Socialism. London: Jonathan Cape.

Dworkin, Ronald M. 1981. "What Is Equality? Part 2: Equality of Resources." Philosophy and Public Affairs 10 (4): 283-345.

Estlund, David M. 1998. "Liberalism, Equality, and Fraternity in Cohen's Critique of Rawls.” The Journal of Political Philosophy 6 (1): 99-112.

Feinberg, Joel. 1970. "Justice and Personal Desert." In his Doing and Deserving: Essays in the Theory of Responsibility, 55-94. Princeton, NJ: Princeton University Press.

Friedman, Milton. 1962. Capitalism and Freedom. Chicago, IL: University of Chicago Press.

Friedman, Milton, and Rose Friedman. 1979. Free to Choose: A Personal Statement. New York, NY: Harcourt Brace Jovanovich.

Hayek, Friedrich A. von. 1945. "The Use of Knowledge in Society." The American Economic Review 35 (4): 519-530.

Hayek, Friedrich A. von. 1960. The Constitution of Liberty. London: Routledge; Kegan Paul.

Hayek, Friedrich A. von. 1976. The Mirage of Social Justice. Vol. 2. Chicago, IL: University of Chicago Press.

Hayek, Friedrich A. von. 2007. The Road to Serfdom. Chicago, IL: University of Chicago Press.

Hazlitt, Henry. 1964. The Foundations of Morality. Princeton, NJ: Van Nostrand.

Heath, Joseph. 2018. "On the Very Idea of a Just Wage." Erasmus Journal for Philosophy and Economics 11 (2): 1-33.

Jackson, Ben. 2007. Equality and the British Left: A Study in Progressive Political Thought, 1900-64. Manchester: Manchester University Press.

Knight, Frank H. 1923. "The Ethics of Competition." The Quarterly Journal of Economics 37 (4): 579-624.

Knight, Frank H. 1940. "Socialism: The Nature of the Problem." Ethics 50 (3): 253-289.

Knight, Frank H. 1947. Freedom and Reform: Essays in Economics and Social Philosophy. Port Washington, NY: Kennikat Press.

Kymlicka, Will. 1990. Contemporary Political Philosophy: An Introduction. Oxford: Clarendon Press.

Lister, Andrew. 2017. "Markets, Desert and Reciprocity." Politics, Philosophy, \& Economics 16 (1): 47-69.

Lister, Andrew. 2018. "The Difference Principle, Capitalism, and Property-Owning Democracy." Moral Philosophy and Politics 5 (1): 151-172.

Mankiw, Gregory N. 2010. "Spreading the Wealth Around: Reflections Inspired by Joe the Plumber." Eastern Economic Journal 36 (3): 285-298.

Mankiw, Gregory N. 2013. "Defending the One Percent." The Journal of Economic Perspectives 27 (3): 21-34.

Miller, David. 1991. "Distributive Justice: What the People Think." Ethics 102 (3): 555593.

Miller, David. 1992. “Deserving Jobs.” The Philosophical Quarterly 42 (167): 161-181.

Miller, David. 1996. "Two Cheers for Meritocracy." The Journal of Political Philosophy 4 (4): 277-301. 
Miller, David. 1999. Principles of Social Justice. Cambridge, MA: Harvard University Press.

Monbiot, George. 2015. "Neoliberalism - the Ideology at the Root of All of Our Problems." The Guardian, April 15, 2015. Accessed September 17, 2018. <https://www.theguardian.com/books/2016/apr/15/neoliberalism-ideologyproblem-george-monbiot>.

Mulligan, Thomas. 2018. Justice and the Meritocratic State. New York, NY: Routledge.

Nagel, Thomas. 1973. "Equal Treatment and Compensatory Discrimination." Philosophy and Public Affairs 2 (4): 348-363.

Nozick, Robert. 1974. Anarchy, State, and Utopia. New York, NY: Basic Books.

Olsaretti, Serena. 2004. Liberty, Desert and the Market: A Philosophical Study. Cambridge: Cambridge University Press.

Plamenatz, John P. 1956. "Equality of Opportunity." In Aspects of Human Equality, edited by Lyman Bryson, 79-110. New York, NY: Harper.

Rawls, John. 1967. "Distributive Justice.” In Philosophy, Politics, and Society, edited by Peter Laslett and Walter G. Runciman, 58-82. Oxford: Oxford University Press.

Rawls, John. 1999. A Theory of Justice. Revised edition. Cambridge, MA: Harvard University Press.

Sandel, Michael. 1982. Liberalism and the Limits of Justice. New York, NY: Cambridge University Press.

Scanlon, Thomas M. 2013. "Giving Desert Its Due.” Philosophical Explorations 16 (2): 101-116.

Sher, George. 1979. "Effort, Ability, and Personal Desert." Philosophy and Public Affairs 8 (4): 361-376.

Thaler, Richard. 1989. "Anomalies: Interindustry Wage Differentials." Journal of Economic Perspectives 3 (2): 181-193.

Tomasi, John. 2012. Free Market Fairness. Princeton, NJ: Princeton University Press.

Van Parijs, Philippe, and Yannick Vanderborght. 2017. Basic Income: A Radical Proposal for a Free Society and a Sane Economy. Cambridge, MA: Harvard University Press.

Williamson, Thad, and Martin O'Neill. 2009. "Property-Owning Democracy and the Demands of Justice." Living Reviews in Democracy 1 (1): 1-10.

Wolff, Jonathan. 1998. "Fairness, Respect, and the Egalitarian Ethos." Philosophy and Public Affairs 27 (2): 97-122.

Young, Michael. 1958. The Rise of the Meritocracy. London: Thames and Hudson

Andrew Lister is Associate Professor of Political Studies at Queen's University (Kingston, Ontario).

Contact e-mail: <andrew.lister@queensu.ca> 